\title{
LUCRÉCIO, CAMÕES E OS DEUSES
}

\author{
Milton L. Torres* \\ Faculdades Adventistas da Bahia
}

\begin{abstract}
RESU MO
Este artigo trata do uso que Lucrécio e Camões fizeram dos deuses da mitologia clássica, por razões pertinentes às convenções da poesia épica e a despeito de sua descrença na existência dos mesmos, sugerindo que ambos constróem os deuses para depois desconstruí-los de forma cabal e definitiva.
\end{abstract}

PALAVRAS - CHAVE

Epopeia, Lucrécio, Camões

Os estudiosos da poesia épica não tentaram ainda explicar, de forma conjunta, por que Lucrécio e Camões, que descriam da mitologia e eram ativos em defender seus próprios pontos de vista religiosos, precisaram contrariar suas ideologias, lançando mão dos deuses para serem protagonistas em seus poemas. Isso não foi questão de escolha. Essa era a exigência das convenções que limitavam e definiam a poesia épica. Será que a tradição épica tinha um pulso tão firme? Sim. Mas tanto Lucrécio quanto Camões descobriram formas convincentes de flexibilizar a tradição em favor de sua própria agenda.

Em resposta à objeção de que "as tradições somente persistem se são percebidas como necessárias," ${ }^{1}$ pode-se argumentar que uma análise assim ainda não conseguiu explicar, de modo satisfatório, por que a tragédia, a mais popular de todas as formas de entretenimento em Atenas, continuou a enfocar tão insistentemente os reis e as famílias nobres, mesmo a despeito da patente irrelevância da estrutura monárquica e de sua hierarquia para as práticas e as instituições democráticas dos atenienses. Certos aspectos da tradição são mais persistentes do que outros: a tradição é especialmente conservadora em relação aos elementos religiosos, pois as inovações ocorrem com menos frequência nessa do que em outras áreas práticas da vida. ${ }^{2}$

Foi a atitude conservadora do mundo clássico em assuntos pertinentes à religião que colocou Lucrécio e Camões em dilemas semelhantes. Lucrécio desejava provar a irrazoabilidade da crença nos deuses fazendo uso da poesia que supôs sua existência. Camões desejava provar a superioridade da religião cristã em relação ao paganismo fazendo uso da poesia que tinha enobrecido os deuses pagãos. ${ }^{3}$ Embora Lucrécio e Camões

\footnotetext{
*miltontorres@yahoo.com.br

${ }^{1}$ GRIFFITH. The King and Eye: The Rule of the Father in Greek Tragedy, p. 21.

${ }^{2}$ APPLETON. Euripides the Idealist, p. 168.

${ }^{3}$ ATKINSON. Camoens' The Lusiads, p. 7. "O verdadeiro herói é o próprio Portugal, especialmente os líderes coletivos que o fizeram grande." GREENE. The Descent from Heaven: A Study in Epic Continuity, p. 226. Todos os textos citados foram traduzidos pelo autor deste artigo.
} 
tenham tentado, de forma ambiciosa, estabelecer a ética de suas próprias agendas religiosas no De rerum natura e Os lusíadas, respectivamente, nenhum dos dois podia prescindir dos deuses, cuja presença imediata nos dois épicos os leitores esperavam.

Lucrécio tentava, de forma inovadora, dissolver os temas da poesia épica para fazer seu conteúdo didático adaptar-se a eles: ${ }^{4}$ seu objetivo como profeta epicureu era provar, por meio da síncrise, que o epicurismo era superior à religião tradicional. ${ }^{5}$ Camões também era um inovador. Esse português escreveu o primeiro poema épico que, em sua grandeza e universalismo, fala para o mundo moderno. ${ }^{6}$ Afinal de contas, ele canta as conquistas de Portugal no século XV que marcam, com significância dramática, as transições da Idade Média para a Idade Moderna e da visão Mediterrânea para uma visão semiglobal.

A tarefa de Camões foi tão difícil quanto a de Lucrécio. ${ }^{7}$ Se Lucrécio tinha uma intenção didática e tentou fazer com que os átomos se tornassem heróis épicos, ${ }^{8}$ Camões escreveu após Virgílio e tentou realizar o prodígio de superar aquele que era admirado como o mestre da epopeia..$^{9}$ A Eneida era, para Camões, tanto modelo quanto desafio. Até no título que escolheu para sua epopeia demonstra um classicismo consciente que instiga a comparação entre a Ilíada e a Eneida.

Da juventude de Petrarca até a época de Milton, a Europa esperara pelo poeta e pelo poema que demonstraria a igualdade da idade moderna com a Antiguidade. A esperança em si não teria sido enganosa se não envolvesse o corolário da semelhança: para contar de fato, a nova obra dever-se-ia assemelhar à Eneida. (...) Em questão também estava (embora somente o eufemismo pudesse indicá-lo) a riqueza imaginativa da religião cristã. Pois se, por um lado, um poeta escolhesse um tema cristão e falhasse, como fizera Chapelain, a falta poderia residir na imprestabilidade do cristianismo para o tratamento épico. Mas se

\footnotetext{
${ }^{4}$ GALE. Myth and Poetry in Lucretius.

${ }^{5}$ SCHRIJVERS. Horror ac divina voluptas: études sur la poétique sur la poésie de Lucrée, p. 309.

${ }^{6}$ BOWRA. From Virgil to Milton, p. 86.

${ }^{7}$ Embora a temática de Camões fosse mais apropriada para a poesia épica, ele não teve vantagens sobre Lucrécio: a herança poética, para Camões, significava Grécia e Roma. ATKINSON. Camoens' The Lusiads, p. 33. Além disso, os portugueses gostavam de pensar que se ligavam, de alguma forma, ao mundo grego. Luso, companheiro de Baco, foi o primeiro explorador mitológico de Portugal. Por isso, os portugueses se chamavam de lusíadas (Os lusíadas 3.21-22a). De modo semelhante, Lisboa, a capital de Portugal por oito séculos, data sua fundação a milhares de anos, atribuindo-a a Ulisses. Camões se refere, mais de uma vez, à fundação daquela metrópole pelo herói da Odisseia, primeiramente no Canto 3.57 e, depois, no Canto 8.4b-5a: "Ulisses é que... Lisboa ingente funda". De acordo com Mickle, a tradição de que Lisboa foi construída por Ulisses, tendo sido, por isso, primeiramente chamada de Ulissópole, é tão difundida e de tanta autoridade quanto a que diz que Brutus desembarcou um contingente de troianos na Inglaterra, chamando-a, por isso, de Bretanha. MICKLE. The Lusiad or The Discovery of India, p. 107.

${ }^{8}$ Para uma discussão dos heróis épicos de Lucrécio, veja-se: GALE. Myth and Poetry in Lucretius. De acordo com a autora, seus protagonistas podem ser: (a) os átomos; (b) Epicuro; (c) o leitor; entre outros.

${ }^{9}$ Camões "sabia o que fazia; pois era um exímio latinista, que conhecia os poetas latinos com o conhecimento íntimo dos apaixonados, e raramente uma página de Os Lusíadas deixa de aludir a eles. Parece que ele não lia grego, mas deve ter tido acesso à tradução latina de Homero por meio da versão de Lourenço Valla". BOWRA. From Virgil to Milton, p. 88.
} 
alguém escolhesse um tema clássico e fracassasse, como Petrarca e Ronsard, o cristianismo poderia ser culpado por produzir um mundo que tornara tão remotos os valores do épico clássico. ${ }^{10}$

Contudo, a despeito da busca por um novo Virgílio e sua rivalidade com seus contemporâneos, ${ }^{11}$ desde os primeiros versos, Camões deixou claro que sua obra seria uma Eneida inédita. ${ }^{12}$ Por isso, Camões põe um distanciamento entre si e Virgílio tanto na métrica quanto na dicção. ${ }^{13}$ Seu objetivo era a exaltação de uma raça de heróis. Ele canta as armas e os barões. O que Portugal tinha realizado no Oriente era, para ele, incomparavelmente superior aos temas da Antiguidade: "Cesse tudo o que a Musa antiga canta que outro valor mais alto se alevanta" (1.3). ${ }^{14}$ Como Milton, Camões é intransigente quanto ao fato de que seu argumento é superior, uma vez que canta realizações que vão muito além das histórias fabulosas de Homero e Virgílio: "A verdade, que eu conto, nua e pura, vence toda grandíloca escritura!" (5.89). ${ }^{15}$

Os dilemas dos autores de De rerum natura e Os lusíadas são semelhantes, uma vez que estes escolhem a epopeia como veículo de suas convicções religiosas, quer para ganhar conversos (no caso de Lucrécio), quer para exaltar os triunfos religiosos de seu próprio povo (no caso de Camões).

\section{LUCRÉCIO E OS DEUSES}

Lucrécio seria uma ilustração adequada da abrangência da fé do ateu, como esta é enunciada por Gibson: fé na liberdade (2.251-293), fé no sexo (4.1052-1057), fé na morte $(1.102-1035 ; 2.45 ; 3.37-93$, 830-1094; 6.1182-1183, 1208-1212), fé na matéria (1.149$264,951-1051 ; 2.294-307)$, fé na finitude e fé no tempo $(5.828,1454-1455) .{ }^{16}$ Seu sistema constitui uma estrutura de natureza semireligiosa que busca solapar radicalmente a religião. Lucrécio não tem fé alguma nos deuses. Não obstante, de modo surpreendente, ele faz inúmeras referências à sua existência. E isso requer que muitas indagações sejam feitas. A que mais nos interessa, aqui, é: por que Lucrécio começa seu poema de forma

\footnotetext{
${ }^{10}$ GREENE. The Descent from Heaven: A Study in Epic Continuity, p. 3.

${ }^{11}$ Para uma discussão da tentativa de Camões de superar Rodomonte, Ruggiero, Boiardo e o Orlando Furioso de Ariosto, veja-se: BOWRA. From Virgil to Milton, p. 120-36.

${ }^{12}$ GREENE. The Descent from Heaven: A Study in Epic Continuity, p. 4.

${ }^{13}$ Ele usa a ottava rima de Ariosto; e, apesar da qualidade clássica de sua dicção, esta é surpreendentemente natural. "Quando o lemos pela primeira vez, dificilmente pensamos em Virgílio; tão bem Camões absorveu os princípios da construção épica e os usou de sua própria maneira". BOWRA. From Virgil to Milton, p. 89.

${ }^{14}$ Todas as citações de Os lusíadas provêm da edição de RAMOS. Os lusíadas de Camões.

${ }^{15}$ Camões "sabia história e geografia [...] até a medula de seu corpo sofrido", mas embora baseasse o poema em episódios realmente ocorridos na história portuguesa, não se trata de um relato factual. GREENE. The Descent from Heaven: A Study in Epic Continuity, p. 219-220. Por isso, Camões tem sucesso tanto por sua imaginação quanto por sua aptidão para a história. GREENE. The Descent from Heaven: A Study in Epic Continuity, p. 207-208.

${ }^{16}$ GIBSON. The Faith of the Atheist. Para uma perspectiva diferente sobre a relação entre fé e ateismo, veja-se: ROBINSON. An Atheist's Values, p. 118-130.
} 
tão provocativa, ao introduzir os deuses, quando seu desejo é se livrar deles? ${ }^{17}$ É isso o que Cook chamou de "uma espécie de contradição dupla ao argumento principal do poema". ${ }^{18}$ Escolhi, por isso, algumas passagens nas quais Lucrécio, de alguma forma, aparentemente endossa o culto aos deuses: a invocação à deusa Vênus no proêmio (1.1-16), a passagem programática em 1.62-79, a descrição do culto de Magna Mater (2.600-660), e sua breve diatribe sobre a religião (5.1198-1203). Seu endosso é apenas aparente, pois usa cada passagem como tijolos para construir a veemente negação da religião romana. A partir da invocação a Vênus, torna o leitor cada vez mais ciente de seu propósito, gradativamente enfatizando sua antipatia pelas práticas religiosas comuns ao povo de Roma.

A invocação a Vênus (1.1-16) é causa de grande perplexidade para os leitores de Lucrécio: "para alguém que quer livrar os homens do temor aos deuses, provando que eles se encontram inteiramente afastados da vida neste mundo e indiferentes a ela, parece estranhamente inconsistente começar com uma prece dirigida a uma divindade específica". ${ }^{19}$ No entanto, este hino pode ser interpretado como uma garantia por parte de Lucrécio a seus compatriotas romanos de que não lhes deseja atacar as convicções religiosas. ${ }^{20}$ Ao mesmo tempo, ainda que correndo o risco de parecer excessivamente simplista, não se pode menosprezar a importância da convenção há muito tempo estabelecida da invocação (aqui, a Vênus, não às musas), na poesia épica, como razão para sua decisão de incluir o hino na abertura do poema: "ele calça sua invocação em termos nitidamente religiosos porque é isso que um romano esperaria ler". ${ }^{21}$ Ao fazer isso, porém, ele propõe um enigma aos leitores que ele somente decifrará mais tarde em sua exposição.

Mesmo os autores de prosa seguiam, às vezes, a norma de prefaciar qualquer obra importante com uma invocação aos deuses. Varrão abre seu tratado intitulado De re rustica com um elaborado apelo aos deuses padroeiros dos fazendeiros. Assim, para os leitores ou ouvintes educados, essas invocações não mais sugeriam a ideia da presença real da divindade; elas meramente forneciam ocasião para a exibição dignificada de um pouco de refinamento literário. Isso ocorre com o discurso de Lucrécio a Calíope (6.94) e as pouco convictas invocações de Ovídio na abertura de As metamorfoses. De modo semelhante, é em conformidade com a tradição poética que Lucrécio faz paródias do estilo dos poetas gregos ao descrever a vitória parcial do fogo sobre os outros elementos da natureza (5.396-410). Com efeito, para um epicureu, não há sol eterno ou pater omnipotens (399).

\footnotetext{
${ }^{17}$ Sedley faz uma indagação semelhante em relação ao fato de Lucrécio introduzir elementos empedocleanos no início do poema, elementos contra os quais vai argumentar posteriormente. Sua resposta é que "o propósito de Lucrécio é estabelecer, desde o começo, o preciso manto literário grego que está vestindo". SEDLEY. The Proems of Lucretius and Empedocles, p. 269-296.

${ }^{18}$ COOK. The Angling of Poetry to Philosophy, p. 196.

${ }^{19}$ BENFIELD; REEVES. Selections from Lucretius, p. 10. Todas as citações de De rerum natura provêm da edição da Loeb Classical Library.

${ }^{20} \mathrm{O}$ proêmio contém certo grau de inconsistência. Segundo Kleve, com o hino, Camões só quer convidar os leitores a que tenham uma melhor compreensão da natureza dos deuses". KLEVE. Lukrez und Venus, p. 94. ${ }^{21}$ SUMMERS. Lucretius and the Epicurean Tradition of Piety, p. 49.
} 
Várias interpretações têm sido propostas para o papel que Vênus desempenha no poema como um todo. Hadzsits a vê como um dos deuses no intermúndio. ${ }^{22}$ Bignone diz que ela representa os princípios epicureus do prazer cinético e do prazer estático. ${ }^{23}$ Hahn a compreende como uma deusa da fertilidade, a contraparte de Epicuro, o criador de ideias. ${ }^{24}$ Para Amory, a identificação da natureza com Vênus coloca o mundo natural em íntima relação com voluptas, o centro da ética dos epicureus. ${ }^{25}$ Sedley sugere que ela representa uma homenagem a um tratado de Empédocles, cujo prefácio, agora perdido, foi dedicado à deusa. ${ }^{26}$ Asmis declara que ela governa com a sedução, substituindo o Zeus dos estoicos, que governa com a providência. ${ }^{27} \mathrm{E}$, finalmente, Summers a vê como símbolo das forças construtivas ou conservadoras do universo. ${ }^{28}$ Só é possível concordar com Summers, no entanto, quando se lê o poema inteiro. Embora ouçamos muito pouco sobre Vênus no resto do poema (mesmo no livro dedicado ao amor), é possível analisar os fenômenos atribuidos a sua influência como os efeitos da organização atômica: os ventos (1.271-297), as nuvens (6.451-534), a criação da vida na terra (5.785-836) e o movimento das constelações (5.509-537). Ainda que essa invocação a Vênus seja muito mais do que um apóstrofe convencional, Lucrécio está invocando uma deusa especialmente admirada pelos romanos. ${ }^{29}$ Ele se dirige a ela como ancestral dos romanos. Ao exaltar Vênus, além disso, ele presta homenagem aos Memmii, de quem ela parece ter sido a padroeira e cujas moedas portam a efígie da deusa.

A despeito do fato de que Lucrécio se conformasse ao exemplo dos poetas de Homero a Ênio, com ele, a invocação não é instância de mera exibição ou diletantismo. Essas linhas exsudam intensa honestidade, o que salienta a ambiguidade do proêmio, porque, enquanto evoca convencionalidade, está repleto de brilhantes imagens. No entanto, essa ambiguidade diminui inexoravelmente nas outras referências, no poema, à deusa. Em 1.228 ela é apresentada como uma força divina que restaura e revigora os elementos; em 2.163, 437; 3.776, a força produtiva de Vênus é meramente identificada com a sexualidade humana e os instintos reprodutivos dos animais. Mais tarde (4.10371287), Lucrécio a chama de "amor" e diz: haec Venus est nobis ("isto é Vênus para nós", 4.1058). No Canto 5, ela é primeiramente comparada às estações (5.737) e, então, mais uma vez, com a sexualidade $(5.848,962,1017)$ e com a paixão $(5.897)$.

\footnotetext{
${ }^{22}$ HADZSITS. The Lucretian Invocation of Venus, p. 187-92.

${ }^{23}$ BIGNONE. Storia della letteratura latina, v. 2.

${ }^{24}$ HAHN. The First Prooemion of Lucretius in the Light of the Rest of the Poem, p. xxxii-xxxiii.

${ }^{25}$ AMORY. Obscura de re lucidi carmina, p. 145-68.

${ }^{26}$ SEDLEY. The Empedoclean Opening, p. 48-87.

${ }^{27}$ ASMIS. Lucretius' Venus and Stoic Zeus, p. 458-470.

28 "A Vênus a quem Lucrécio invoca não pode ser deusa alguma já que os deuses não são forças influentes. Eles são antissociais, inativos e inertes; não se envolvem em casos de amor, nem há disputas entre eles; não se iram, não protegem nem auxiliam, nem tampouco atendem às orações (1.44-9). Quando o poeta invoca uma Vênus, que é capaz de, ao contrário, fazer todas essas coisas, trata-se da personificação poética de uma força operante, mas destituida de sentimento." SUMMERS. Lucretius and the Epicurean Tradition of Piety, p. 49.

${ }^{29}$ Virgílio a fez mãe do povo romano quando escolheu Eneias para ser o herói do épico romano. Dessa forma, "Lucrécio aqui fala como patriota romano". BENFIELD; REEVES. Selections from Lucretius, p. 11.
} 
Percebe-se que Lucrécio encontra seus leitores onde estes se encontram, ${ }^{30}$ quando se comparam as referências acima com o papel que Vênus desempenha no poema. No entanto, é preciso examinar o contexto de todo o poema. Lucrécio sabe que o objetivo do poeta não é apresentar a verdade de forma incondicional, mas comover os leitores. Daí sua imagem da colher adocicada com mel para a ministração de um medicamento de sabor amargo, constituindo seu discurso sob a forma de instrução a um jovem aprendiz $(4.11-21)$.

O poeta sabe que não deveria ser direto demais na abordagem de seu tema e, por isso, busca ser explícito sem ser inconveniente. Está ciente de que seu objetivo demanda esforço e se dispõe a satisfazer essa exigência (6.917-920). Lucrécio sabe também que a melhor lógica é, muitas vezes, a que apela ao coração e não necessariamente ao intelecto. Nosso poeta não é um manipulador, no entanto. Sua instrução pende para a consolação, segundo os princípios da psicagogia filosófica. ${ }^{31}$

Na passagem programática de Lucrécio em 1.62-79, "os deuses são pegos na tensão do negativo". ${ }^{32}$ São eles que se opõem a Epicuro, com seus raios e trovões ameaçadores. Ele é o viajor alquebrado que atravessa o universo imensurável no pensamento e na imaginação. Ele é o herói; eles são os vilões. De acordo com Gale, é a "estratégia do poema como um todo deificar a Epicuro". ${ }^{33}$ Lucrécio progressivamente o revela como tal: primeiramente, como homem (1.70 et seq); a seguir, como semidivino (proêmio do Canto 3); e, finalmente, como deus (5.8). O próprio fato de que Epicuro é descrito como ser divino sugere uma degradação dos deuses por meio de um processo de evemerização.

Portanto, Lucrécio transforma a tranquilidade imperturbável de Epicuro em um esforço extenuante para o triunfo da clareza intelectual. ${ }^{34}$ Ele volta com o prêmio do conhecimento, mas a religião dos deuses é jogada por terra. Lucrécio nunca emprega a palavra superstitio. Religio e superstitio significam, para ele, a mesma coisa, e ele acentua a ligação da superstição com as regiões celestiais ao incluir as letras de religione na expressão caeli regionibus (1.64). ${ }^{35}$ Alguns defendem a ideia de que, embora abominasse a religião tradicional, Lucrécio deixava espaço para uma religião positiva. ${ }^{36}$ Entretanto, essa proposição parece não ser inteiramente verdadeira dado seu escrutínio impiedoso das práticas religiosas dos romanos. Além disso, Lucrécio parece apaixonado demais para que se suponha que recorra a mero artifício retórico. Com efeito, até mesmo o estilo usado para denegrir a religião "trai uma trepidação secreta", e, em vez da indiferença filosófica, manifesta um ódio amargo que procede de uma mente "profundamente perturbada". ${ }^{37}$

\footnotetext{
${ }^{30}$ SUMMERS. Lucretius and the Epicurean Tradition of Piety, p. 48.

${ }^{31}$ Para uma exposição minuciosa da psicagogia dos epicureus, veja-se: ARMSTRONG. All Things to all Men. ${ }^{32}$ COOK. The Angling of Poetry to Philosophy, p. 203.

${ }^{33}$ GALE. Myth and Poetry in Lucretius, p. 192. Vênus, Atena, Zeus e Hélios são assimilados a Epicuro.

${ }^{34}$ COOK. The Angling of Poetry to Philosophy, p. 217, n. 27.

${ }^{35}$ FRIEDLÄNDER. The Pattern and Sound and Atomistic Theory in Lucretius, p. 16-34.

${ }^{36}$ BENFIELD; REEVES. Selections from Lucretius, p. 14. BAILEY. De Rerum Natura of Lucretius, v. 1, p. 71.

${ }^{37}$ LEWIS. Plato contra atheos, p. 227.
} 
$\mathrm{Na}$ descrição da Magna Mater (2.600-660), muitas de suas funções são aquelas que Lucrécio já havia atribuido a Vênus, e a justificativa que dá para seus ritos também parece sancioná-los. Porém ele rejeita tudo isso como irrazoável: (...) a vera ratione repulsa (2. 645). Para o poeta, o divino e o eterno estão ligados tão intimamente quanto o são o divino e a paz (2.646-251). Por sua própria natureza (per se, cf. 2.646), os deuses desfrutam de existência eterna semelhante aos átomos que, juntamente com o vácuo, possuem essência perene e independente (per se, cf. 1.419). Em consequência disso, os deuses, bem como os átomos e o vácuo, são revestidos de uma imortalidade que é inerente à sua natureza. Por isso, pode-se dizer que Lucrécio não descrê nos deuses. Ele simplesmente descrê de seu interesse pelos assuntos humanos, e isso os torna inúteis para a religião romana. Como resultado, ele permite que os homens chamem o mar de Netuno, o cereal de Ceres, o vinho de Baco e a terra de "mãe dos deuses", desde que não cedam à religio (2.655-660). Essa religio equivale a um aprisionamento no horror supersticioso que incapacita o homem a acolher a lição pacificadora e liberadora do fluxo atômico universal dos epicureus, cf. 1.62-63. Afinal de contas, desde o início de seu poema Lucrécio declara que é a ignorância das leis da natureza que obrigou o homem a venerar os deuses (1.146-158).

Destarte, há uma repetida ênfase, da parte de Lucrécio, no fato de que um conhecimento preciso das leis da natureza desabonará quaisquer formas de superstição religiosa $(1.146-8 ; 2.59-61 ; 3.91-3 ; 6.39-41)$. É, portanto, a ignorância das leis naturais que fomenta a crença nos deuses (cf. 1.151-4; 5.1183-7; 6.50-5). Além disso, ao usar a expressão religione turpi para se referir à religião (2.660), Lucrécio não está postulando a existência de tipos diferentes de religião, uma forma degradada e outra nobre; o que ele quer dizer é que todas as formas de religião são vis. Isso fica claro na breve diatribe que usa para atacar a religião, em 5.1198-1203.

$\mathrm{Na}$ diatribe sobre a religião (5.1161-1193), Lucrécio explica a origem do culto tradicional. Ele analisa a concepção que o homem comum tem dos deuses: este imagina os deuses como seres sobre-humanos dotados de beleza e poder incomparáveis (5.11691174). Toda vez que o homem pensa nos deuses, essas imagens povoam sua imaginação. Isso significa que seus simulacros atômicos alcançam o homem. Essas visões de poder e beleza precisamente têm levado os homens a considerar que os deuses são eternos (cf. 5.1175-1178). Ao mesmo tempo, uma vez que são apropriadamente associados à imortalidade, os deuses são, então, incorretamente associados com uma existência idílica e prazerosa derivada dela $(5.1179-1182)$. Lucrécio, por outro lado, se distancia dessa visão, porque não percebe conexão alguma entre a imortalidade dos deuses e sua vida de prazeres. Os deuses levam uma vida feliz não porque estão isentos do medo da morte, mas porque se encontram alheios às coisas humanas (cf. 2.647). Por isso, "não se estabelece nenhuma relação de dependência entre a eternidade e a bem-aventurança dos deuses". ${ }^{38}$

Depois de explicar a origem da religião, Lucrécio avança para a desconstrução das práticas religiosas romanas. Com uma breve diatribe acerca da religião (5.1198-1203),

${ }^{38}$ SCHRIJVERS. Horror ac divina voluptas, p. 63. 
ele se apresenta, a essa altura, mais confortável com a revelação de toda a verdade quanto aos deuses. Ele ainda sente que é necessário adocicar, com mel, a colher cheia de remédio, mas seu ataque à tradição religiosa dos romanos é agora muito mais patente (5.1198-1203). Dessa vez, ele ataca menos cautelosamente a totalidade da experiência religiosa dos romanos, seja esta pública ou privada: o velamento da cabeça, o recurso a pedras e juramentos, a supplicatio, a prostração, a oração, o sacrifício e os votos. De fato, a partir do Canto 5, Lucrécio, abertamente, revela seu desprezo pelos templos e pelas estátuas dos deuses (cf. 5.306-310; 6.68-79, 417-420, 1272-1277). Assim, gradualmente, o poeta remove as muletas de seus leitores.

De fato, Lucrécio não cumpre sua promessa de considerar minuciosamente a questão dos deuses (quae tibi posterius largo sermone probabo, "isso te provarei mais tarde com um discurso amplo" 5.155). ${ }^{39}$ Uma vez que sente que já convenceu os leitores, não mais julga necessário se demorar em um tema que pode acabar prejudicando seus propósitos doutrinários. O movimento que se observa no poema de Lucrécio é o que parte da cautela para a franqueza. ${ }^{40}$ No plano mental, se desloca do aparente endosso aos deuses para a absoluta rejeição dos mesmos. Lucrécio pode estar tentando dar uma impressão temporária de religiosidade com sua invocação a Vênus, mas toda outra menção da religião, no poema, ou tem claras conotações alegóricas ou é nitidamente negativa. ${ }^{41}$ Contudo, ele não escreve com viés dissimulado. $O$ poeta simplesmente cuida para que sua teoria atômica não cause pânico aos romanos. ${ }^{42} \mathrm{E}$, ainda que Sêneca afirme que só as crianças dão crédito aos mitos que os epicureus atacam, ${ }^{43}$ Lucrécio está mais do que atacando os mitos. Como Lactâncio afirma, o poeta mina o culto pagão sem pretender substituí-lo. ${ }^{44}$

O tom de Lucrécio para com os deuses deve ser considerado adaptativamente responsivo e intermitente, até mesmo sincrético, enquanto que Epicuro não se exime de absorvê-los placidamente na perspectiva de seu sistema. ${ }^{45}$ A esse respeito, Lucrécio representa um rompimento com Epicuro. Embora Epicuro tivesse rejeitado a maior parte das noções tradicionais acerca dos deuses e seu interesse em relação aos assuntos humanos, ele ainda encorajava seus admiradores a que tomassem parte nos cultos com seus compatriotas. Em contraste com a abordagem de Epicuro, Lucrécio mina as razões para a realização dos rituais. ${ }^{46}$ Religio e superstitio representam conceitos análogos para

\footnotetext{
${ }^{39}$ Talvez ele desejasse fazê-lo, mas tenha sido impedido devido à natureza inacabada do poema. Talvez tenha mudado de ideia. E não é impróprio supor que sua promessa fique sem cumprimento porque nunca tenha tencionado levá-la avante.

${ }^{40}$ E quanto movimento há nesse poema! A despeito de sua profissão ortodoxa de que se deve desejar a ataraxia, o poeta prefere encarar o universo como a própria expressão da inquietude. AMORY. Obscura de re lucidi carmina, p. 168. De fato, "o poema se movimenta com uma facilidade e rapidez desconcertantes, do plano físico para o plano mental ou espiritual”. ELDER. Lucretius 1.1-49, p. 91.

${ }^{41}$ SUMMERS. Lucretius and the Epicurean Tradition of Piety, p. 51.

${ }^{42}$ CLAY. Lucretius and Epicurus.

${ }^{43}$ Epistula 24.18. Esse é também o sentimento que transparece do De natura deorum, de Cícero, e do De antiquitate rerum divinarum, de Varrão.

${ }^{44}$ Div. inst. 2.3-4.

${ }^{45}$ COOK. The Angling of Poetry to Philosophy, p. 196.

${ }^{46}$ SUMMERS. Lucretius and the Epicurean Tradition of Piety, p. 43.
} 
ele. Por isso, religio constitui o alvo principal de sua invectiva. ${ }^{47}$ Ainda assim, o poeta nunca abandona os princípios de uma psicagogia cuidadosa que busca implementar uma uma atitude de descrença sem chocar seus leitores (non quo violari summa deum vis posit, "não que o supremo poder dos deuses seja passível de insultos" (6.71).

A elaborada e aparentemente enganosa construção que Lucrécio faz dos deuses, na abertura do poema, constitui parte de um plano que vai culminar com a desconstrução de tais divindades logo depois que ele estabelece os fundamentos de sua teoria atômica. Esse procedimento se assemelha à ação também adotada por Camões, como veremos a seguir.

\section{CAMÕES E OS DEUSES}

A saga de Camões, como a Eneida, gira em torno de um marinheiro atormentado pelas tempestades, que se aventura no desconhecido a fim de criar um segundo Império Romano. Com efeito, é por intermédio de mecanismos tomados de empréstimo principalmente de Virgílio que o problema de interligar o passado com o presente e o futuro é resolvido. É justamente por causa disso que Camões se vê apanhado em um dilema: para os efeitos da poesia ética, não há como substituir os deuses da mitologia greco-romana por Deus e Seus anjos. ${ }^{48}$ Era necessário um escopo mais imaginativo do que a vida de Cristo e a Bíblia permitiam. Além disso, havia o prestígio contínuo do humanismo entre os poetas cristãos. Desde Vida até Milton, o risco em que o épico cristão sempre incorreu foi o da escassez de ação objetiva. ${ }^{49}$ Por isso, perguntava-se se Camões seria capaz de construir, em um poema distintivamente cristão e escrito para exaltar uma nação engajada em uma cruzada secular pela fé, ${ }^{50}$ estribado na necessidade de se referir frequentemente àquela fé e àquela cruzada, a parte desempenhada pelas divindades da Antiguidade pagã. Conseguiria ele incluir os deuses do antigo mundo greco-romano em seu épico quando "a audácia de misturar elementos pagãos e sagrados em quaisquer proporções era uma causa de crescente inquietação em diversos lugares, muito antes de Boileau denunciar o mélange coupable?" ${ }_{11}$

Alguns estudiosos prefeririam ver Os lusíadas como a epopeia do comércio, reservando o título de poema épico da religião para o Paraiso perdido. ${ }^{52}$ No entanto, quer desejemos atribuir à religião o papel principal ou não, a importância desse elemento, no épico, é inegável. ${ }^{53}$ Há quatro tipos de deuses na obra de Camões e eles estão sempre

\footnotetext{
${ }^{47}$ Para uma opinião diversa, veja-se: SPRINGER. The Role of Religio, Solvo and Ratio in Lucretius, p. 55-61.

${ }^{48}$ ATKINSON. Camoens' The Lusiads, p. 22.

${ }^{49}$ GREENE. The Descent from Heaven: A Study in Epic Continuity, p. 206.

${ }^{50}$ De acordo com Bowra, Camões "não deseja nada menos do que uma cruzada europeia contra o Islã. Seu primeiro objetivo é expulsar os 'cães' do Sepulcro Sagrado.” BOWRA. From Virgil to Milton, p. 134.

${ }^{51}$ GREENE. The Descent from Heaven: A Study in Epic Continuity, p. 3.

${ }^{52}$ MICKLE. The Lusiad or The Discovery of India, p. i.

53 "O senso camoniano e cristão de fragilidade, de fato, não conflita com sua celebração épica das conquistas humanas, mas cria uma espécie de tensão em razão de sua coexistência na obra, uma tensão que lhe concede, abaixo da superfície, uma enriquecedora vitalidade dramática". GREENE. The Descent from Heaven: A Study in Epic Continuity, p. 227.
} 
presentes no épico. ${ }^{54}$ De fato, é Júpiter quem profetiza, pela primeira vez, o futuro glorioso dos portugueses (2.44-55). Vênus, por outro lado, dirige a armada das costas de Quiloa, por meio de ventos contrários (1.100) e impede os portugueses de entrar no porto de Mombaça (2.18-24). Baco finge ser um sacerdote cristão para enganá-los (Canto 2) e, posteriormente (Canto 7), aparece em sonho aos muçulmanos a fim de os indispor contra os portugueses. No final do Canto 6, as ninfas acalmam os ventos, o que torna possível que os portugueses finalmente alcancem a Índia no Canto 7. Elas também lhes proveem descanso por ocasião de sua chegada à divina Ilha do Amor (9.18-88). Finalmente, Tétis oferece um banquete para que os portugueses celebrem suas realizações e mostra a Vasco da Gama uma miniatura do universo onde lhe aponta os feitos gloriosos dos poderosos portugueses do futuro. Além disso, é ela quem despede os marinheiros a caminho de casa (10.143).

Camões usa os deuses para publicar sua crença de que Portugal era o sucessor natural de Roma. Ele recorre ao pai dos deuses, que antes favorecera os romanos, para predizer as venturas de Portugal, e a Vênus, para mostrar que a deusa da fundação de Roma também ama a Portugal (cf. 1.33). A ela se opõe, não Juno, mas Baco, escolhido por causa de sua conexão com a Índia e por ser um símbolo da vaidade comumente associada com o Oriente. Por isso, Vênus e Baco corporificam os poderes sobrenaturais que ajudam ou prejudicam os portugueses. Estes representam, para Camões, os defensores da civilização e do cristianismo contra os poderes corruptores do Islã e da barbárie.

A despeito de seu valor no poema, a concepção cristã de vida do poeta o compele a desconstruir os deuses. Apesar disso, os deuses de Camões não são deuses de porcelana:

No espírito do Poeta renascente, cabem, lado a lado, a crença cristã e a compreensão do sentido profundo das velhas crenças extintas... São deuses do paganismo destronado pela Religião de Jesus; mas foram, no mundo antigo, tentativa de explicação dos mistérios em que o homem jazia mergulhado..$^{55}$

Sua desconstrução ocorre principalmente no Canto 9, na ilha de Vênus (89-92), um plano executado caprichosamente. Ele começa pelas ninfas, transformando-as nos charmes da honra (9.89) e, então, prossegue com outros deuses e semideuses. Agora explode a noção da existência de divindades que ele havia ajudado a construir, pois apresenta-as

\footnotetext{
${ }^{54}$ No primeiro nível, há as divindades que interferem, de modo indireto, no desenvolvimento da trama, sempre recorrendo a outras divindades a fim de alcançar seus objetivos. Assim, Júpiter e Netuno agem como juizes cósmicos. Os dois concílios que dirigem, no céu e no fundo do mar, correspondem a seu envolvimento mais intenso no enredo. O senhor dos mares se opõe às deliberações do pai dos deuses. Por causa de sua inteira autonomia, Marte, Vênus e Baco pertencem a uma segunda categoria. Baco prejudica abertamente os portugueses, enquanto Vênus lhes presta ajuda. Marte é o conselheiro de Júpiter e lhe dá sugestões conforme as persuasões de Vênus. Em um terceiro nível, encontram-se as divindades que obedecem às ordens das entidades mais poderosas, segundo às quais interferem na trama: Adamastor, Noto e Éolo (contra os portugueses) e as nereidas, Tétis e as ninfas (a seu favor, quando os marinheiros o merecem). Finalmente, em um quarto nível, encontram-se as divindades que agem como mensageiros dos deuses para com os homens: Mercúrio (2.56-9) e Tritão (6.16-19).

${ }^{55}$ RAMOS. Os Lusíadas de Luís de Camões, p. 48.
} 
apenas como homens com características heróicas. Foi a fama que os tornou deuses e os descreveu como filhos de deuses, mesmo sendo seres humanos como nós (9.90-92)..$^{56}$

A partir do Canto 9, deuses e deusas se retiram do palco principal e assumem papéis muito menos importantes, limitando-se a anunciar profecias sobre o brilhante futuro dos portugueses e não mais interferindo na ação central. Também passam a exibir uma atitude muito mais moralizante, uma vez que sua fala passa a refletir princípios que são inteiramente cristãos. De fato, o último episódio do épico é assim marcado por uma emergência mais marcante de valores cristãos, especialmente destacando os milagres de São Tomé, mártir cristão, na Índia (10.108-19). Tétis ia repreender as nações do século XVI que professavam o cristianismo mas não agiam em conformidade com sua fé, quando Camões recorre a São Tomé como ponte para o pronunciamento da ninfa. Escolhe-o porque aquele que sucumbira ao ceticismo passageiro e tocara o lado traspassado de Jesus se tornara um exemplo de nossa própria resistência à crença em fatos extraordinários.

Alguns críticos consideram que a tentativa de misturar os deuses pagãos e os personagens bíblicos fracassou. A atitude aparentemente sincrética do poeta, que os críticos chamam de confusão cósmica do poema, merece, de alguns, a mais violenta condenação. ${ }^{57} \mathrm{O}$ que os críticos parecem não perceber é que há uma razão por que os deuses são irrelevantes para Camões. Seu propósito, desde o princípio, é provar a superioridade do cristianismo sobre o paganismo. Não é que saiam do controle do autor, eles são intencionalmente menosprezados por ele. Não apenas são secundários, mas gradualmente saem de cena. Fornecem-lhe um escopo imaginativo, mas são descartados quando não mais necessários. Camões abre, de uma vez por todas, o caminho para um épico inteiramente cristão, como é o caso do de Milton, por exemplo.

Do início ao fim do poema, Camões nos informa que suas divindades são apenas os símbolos das atividades do Deus supremo $(1.21 ; 10.83)$. Em resumo, os deuses de Camões podem ser tomados como símbolos dos heróis, da natureza e do Deus dos cristãos, mas sua ocorrência no poema se deve às convenções da poesia épica. De acordo com Tavares,

Onde melhor se aprecia essa capacidade de materialização dessas forças é na personificação das últimas dificuldades de navegação que os Portugueses enfrentam na figura de Adamastor, genial concepção de Camões, que conjura um gigante típico da mitologia clássica e lhe dá um tal sopro de vida que, de todos os gigantes da ficção, é o que tem a personalidade mais viva e cuja estatura apresenta maior consistência. ${ }^{58}$

\footnotetext{
56 "Conquanto, além disso, Deus seja o Supremo Poder e todas as coisas obedeçam a Seu beneplácito, os deuses foram, tradicional e principalmente, apenas interpretações figuradas das misteriosas e às vezes conflitantes forças da Natureza; e a conquista portuguesa foi tanto um triunfo sobre tais forças quanto sobre inimigos humanos. Adamastor, em qualquer interpretação cristã, nada mais era do que um promontório. Que sua figura se erga como medida do ganho imaginativo que Os lusíadas derivaram da retenção camoniana da mitologia clássica.” ATKINSON. Camoens’ The Lusiads, p. 23.

57 "O fracasso do autor não diminui, de fato, com a previsível identificação de Júpiter com a providência cristã no canto final, nem pela explicação evemerística dos deuses inferiores. Trata-se de um fracasso. Talvez a mais lamentável de todas as tentativas de arriscar a fantasia pagã sem o escândalo cristão. A única surpresa é que o poema não entre em colapso imediatamente por causa desse fracasso. Se isso não ocorre, sua resistência pode se dever à firmeza de seu foco neste mundo, um foco que tende a tornar todas as intervenções convencionais por parte dos deuses irrelevantes para o assunto principal do poema." GREENE. The Descent from Heaven: A Study in Epic Continuity, p. 225.
}

${ }^{58}$ TAVARES. Deuses, mitos e lendas: mitologia n'Os lusíadas, p. 437. 
Assim, não é que Camões tenha "determinado introduzir elementos pagãos a qualquer custo da coerência". ${ }^{59}$ Ele entrou em competição com os poetas da Antiguidade, e seus heróis, com as figuras das lendas antigas. No entanto, ele diminui a pujança dos deuses pagãos para suplantá-los com o recurso às próprias convenções da epopeia. Camões, por exemplo, "indulge em sua imaginação pitoresca" quando leva Baco a adorar o Deus cristão (2.12). ${ }^{60}$

Ao chegar ao final do poema, Camões tanto quebrou a convenção épica quanto conseguiu preservar o espírito da epopeia. Fez isso, porém, sem dar a impressão de artificialidade ou impostura. ${ }^{61}$

\section{Considerações finaIS}

Lucrécio e Camões são herdeiros de tradições épicas que dependiam grandemente do uso da mitologia antiga. Lucrécio herda a tradição da epopeia grega e Camões é recipiente da tradição épica greco-romana. Por outro lado, ambos são iniciadores de suas próprias tradições: Lucrécio leva a epopeia a um novo nível, enriquecendo-a de maneira formidável com um elemento didático que não podia prescindir dos deuses antigos, mas que foi capaz de suplantá-los. Ele mina a confiança nos deuses, mas não os substitui. Camões dá um passo além e preenche as lacunas, desconstruindo os deuses pagãos e oferecendo, como seus substitutos, uma hierarquia católica de santos e entidades espirituais. Ele consegue fazer o que outros haviam tentado, mas fracassado.

O cuidado com que Lucrécio faz explodir cada convicção religiosa é o mesmo com que Camões emprega os deuses antigos. Ambos estavam sujeitos à intolerância religiosa e, por isso, precisavam exercer cautela ao escrever. ${ }^{62}$ Trata-se de um impasse semelhante: por causa das convenções da epopeia, nenhum dos dois poetas podia prescindir dos deuses e, por causa de suas próprias convicções filosóficas e religiosas, nenhum deles podia incluí-los, de graça, em suas obras-primas.

\section{A}

\footnotetext{
${ }^{59}$ GREENE. The Descent from Heaven: A Study in Epic Continuity, p. 225.

${ }^{60}$ BOWRA. From Virgil to Milton, p. 112.

${ }_{61}$ "É imensamente para crédito seu que ele encontrou lugar em seu poema para [...] uma negação da poesia épica." GREENE. The Descent from Heaven: A Study in Epic Continuity, p. 230-231.

${ }^{62}$ Quando Greene (The Descent from Heaven: A Study in Epic Continuity, p. 182), por exemplo, discute o caso de Tasso, ele afirma que "receoso de ofender a Inquisição, por um lado, e o público culto, por outro, submeteu seus poemas aos censores, cujos escrúpulos atrasaram sua publicação e precipitaram a loucura do poeta". As restrições teológicas da época de Camões eram, porém, muito menos inibidoras do que as da Idade Média. Ele não foi tocado pela Contra-Reforma. Por isso, "o que nem mesmo Ariosto conseguiu fazer, Camões fez alegre e confiantemente. Suas divindades desempenham uma parte indispensável no poema, que seria muito mais pobre sem elas... ao aderir a essa convenção da epopeia, Camões obtém um sucesso triunfal.” BOWRA. From Virgil to Milton, p. 116.
} 


\section{A B S T R A C T}

This paper suggests that Lucretius and Camoens used the gods of Classical mythology due to the conventions of epic poetry and despite the fact that they did not believe in their existence, because both authors needed to adequately construe the gods in order to ultimately deconstruct them.

\section{KEYWORDS}

Epic poetry, Lucretius, Camoens

\section{REFERÊNCIAS}

AMORY, Anne. Obscura de re lucidi carmina: science and poetry in De rerum natura. Yale Classical Studies. New Haven, CT, n. 21, p. 145-168, 1969.

APPLETON, R. B. Euripides the Idealist. Londres: J. M. Dent \& Sons, 1927. 206 p.

ATKINSON, William C. Camoens' The Lusiads. Harmondsworth: Penguin, 1952. 250 p. ARMSTRONG, D. All Things to all Men: Philodemus' Model of Therapy and the Audience of De morte. In: FITZGERALD, J. T.; OBBINK, D.; HOlLAND, G. S. Philodemus and the New Testament world. Novum Testamentum Suppl., Leiden, n. 111, 2004. p. 15-54.

ASMIS, Elizabeth. Lucretius' Venus and stoic Zeus. Hermes: Zeitschrift für klassische Philologie. Berlin, n. 110, p. 458-470, 1982.

BAILEY, Cyril. De rerum natura of Lucretius. Oxford: Clarendon, 1947. v. 1. 582 p.

BENFIELD, G. E.; REEVES, R. C. Selections from Lucretius. Oxford: Oxford University Press, 1967. $164 \mathrm{p}$.

BIGNONE, Ettore. Storia della letteratura latina. Firenze: Sansoni, 1945. v. 2. 599 p.

BOWRA, C. M. From Virgil to Milton. New York: MacMillan, 1967. 255 p.

CLAY, Diskin. Lucretius and Epicurus. Ithaca: Cornell University Press, 1983. 361 p.

COOK, Albert. The Angling of Poetry to Philosophy: The Nature of Lucretius. Arethusa, Baltimore, MD, n. 27, p. 193-222, 1994.

ELDER, John P. Lucretius 1.1-49. Transactions of the American Philological Association, Baltimore, MD, n. 85, p. 88-120, 1954.

FRIEDLÄNDER, Paul. The Pattern and Sound and Atomistic Theory in Lucretius. American Journal of Philology, Baltimore, MD, v. 62, n. 1, p. 16-34, 1941.

GALE, Monica. Myth and Poetry in Lucretius. Cambridge: Cambridge University Press, 1994. $260 \mathrm{p}$.

GIBSON, Arthur. The Faith of the Atheist. New York, Harper \& Row, 1968. 218 p.

GREENE, Thomas. The Descent from Heaven: A Study in Epic Continuity. New Haven: Yale University Press, 1963. 434 p.

GRIFFITH, M. The King and Eye: The Rule of the Father in Greek Tragedy. Proceedings of the Cambridge Philological Society, Cambridge, n. 44, p. 20-84, 1998. 
HADZSITS, G. D. The Lucretian Invocation of Venus. Classical Philology, Chicago, n. 2, p. 187-192, 1907.

HAHN, E. A. The First Prooemion of Lucretius in the Light of the Rest of the Poem. Transactions of the American Philological Association, Baltimore, MD, n. 72, p. xxxii-xxxiii, 1941.

KLEVE, Knut. Lukrez und Venus. Symbolae Osloenses, Oslo, n. 41, p. 86-94, 1966.

KLEVE, Knut. Lucretius in Herculaneum. Bolletino del Centro internazionale per lo studio dei papyri ercolanesi (Cronache ercolanesi), Napoli, n. 19, p. 5-27, 1989.

LEWIS, Taylor. Plato contra Atheos: Plato Against the Atheists, or, Tenth Book of the Dialogue on Laws. New York: Harper, 1845. 372 p.

LUCRÉCIO. De rerum natura. Trans. W. H. D. Rouse. The Loeb Classical Library. Cambridge: Harvard University Press, 1975. 602 p.

MICKLE, William Julius (Trad.). Camoens' The Lusiad or The Discovery of India. 5. ed. New York: Garland, 1979. 484 p.

RAMOS, E. P. Os Lusíadas de Luís de Camões. 4. ed. Oporto: Porto Editora, 1980. 185 p. ROBINSON, Richard. An Atheist's Values. Oxford: Clarendon, 1964. 256 p.

SCHRIJVERS, P. H. Horror ac divina voluptas: études sur la poétique et la poésie de Lucréce. Amsterdam: Hakkert, 1970. 367 p.

SEDLEY, David. The Proems of Lucretius and Empedocles. Greek, Roman and Byzantine Studies. Durham, NC, n. 30, p. 269-296, 1989.

SEDLEY, David. The Empedoclean Opening. In: GALE, Monica R. (Ed.). Oxford Readings in Classical Studies: Lucretius. Oxford: Oxford University Press, 2007. p. 48-87.

SPRINGER, Lawrence A. The Role of Religio, Solvo and Ratio in Lucretius. The Classical World, Montclair, NJ, n. 71, p. 55-61, 1977.

SUMMERS, Kirk. Lucretius and the Epicurean Tradition of Piety. Classical Philology. Chicago, v. 90, n. 1, p. 32-57, 1995.

TAVARES, Jorge C. Deuses, mitos e lendas: mitologia n'Os lusíadas. Oporto: Lello \& Irmão, 1992. 292 p. 